
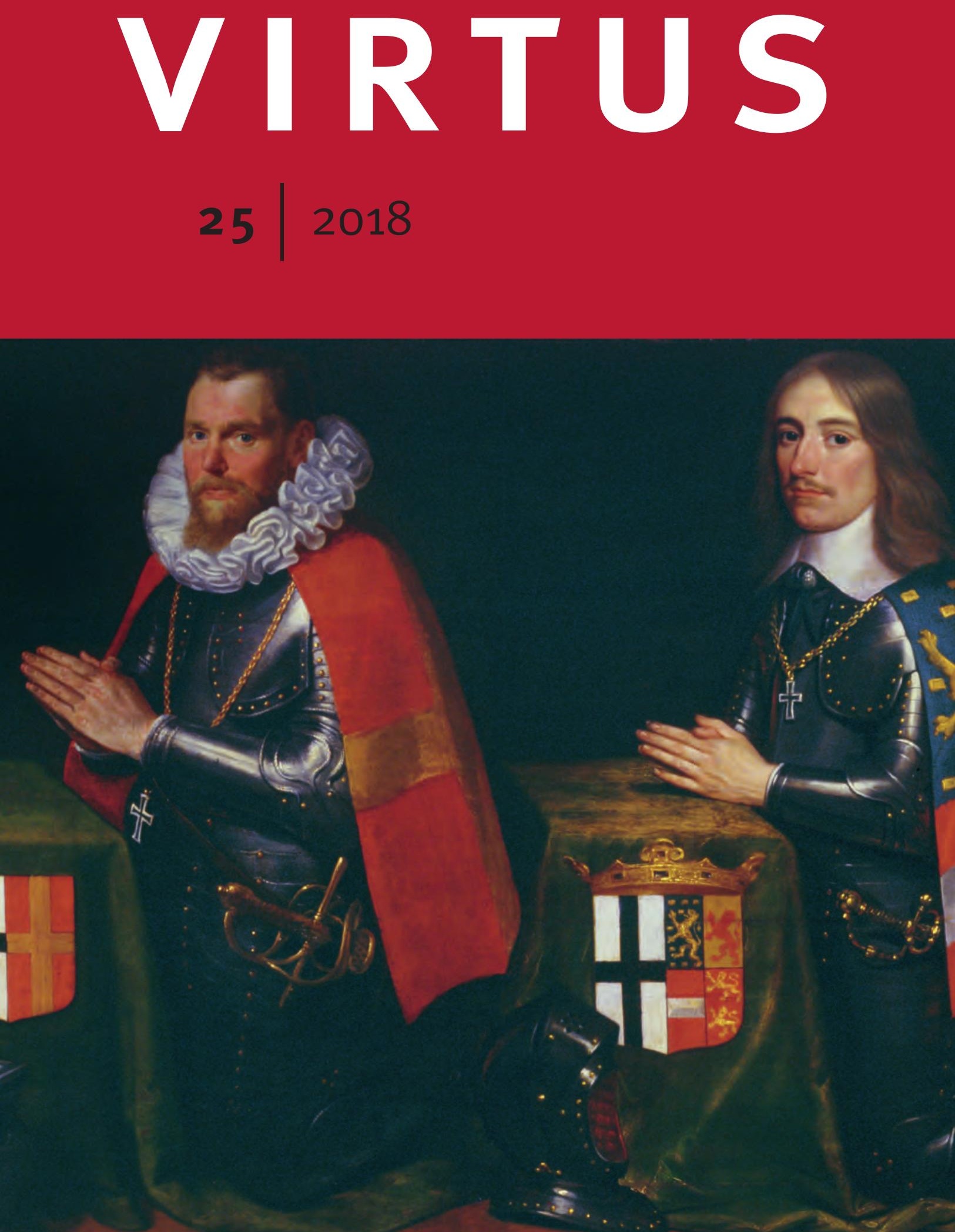


\section{Jaap Geraerts}

\section{Gentry churches in medieval England}

Nigel Saul, Lordship and faith. The English gentry and the parish church in the Middle Ages (Oxford: Oxford University Press, 2017, vi + 384 p., ill., index)

In Lordship and faith, Nigel Saul, Emeritus Professor of Medieval History at Royal Holloway, University of London, examines the relationships between the English gentry and parish churches in the Middle Ages. In doing so, Saul has chosen to cover a long period, starting with the Norman conquest of England in the eleventh century and ending in the decades preceding the Protestant Reformation. In fourteen chapters (including the introduction and conclusion), he examines the relationships between the English gentry and parish churches through different angles and a variety of topics, such as the ties between the gentry and monasteries, household devotion, church architecture, and notions of lordship. According to him, the period under study reveals a movement of the gentry away from monasteries to the parish church, an institution which gained importance for the religious, social, and political life of the gentry as their powerbase became increasingly localized and territorial in nature.

The book's time frame is one of its main strengths. Expertly, Saul traces and links various religious, social, and political developments which spurred the greater investment of the gentry in parish churches, culminating in the creation of a significant number of 'gentry churches' over the course of the late thirteenth and fourteenth centuries and thereafter (5). First, the contours of the gentry as a distinct class became increasingly clear from around the late twelfth century but did not become 'fully developed' until the last quarter of the thirteenth century $(8,299)$. This landed elite, 'the landowning class below the aristocracy', became increasingly attached to the localities in which they owned land and held adminis- 
trative positions. Due to the strengthening ties between the gentry and the localities over which they held sway, they started to identify 'with the shire rather than feudal honour', a development which was spurred in part due to the legal reforms of the Angevins (83, 15960). In addition to these important socio-political developments, Saul points at a number of significant religious changes of which the emergence of chantries was the most important. Originating around 1200, chantries emerged in response to the 'burden of intercession', an even-expanding task that was mainly in the hand of communities of regular priests in the many monasteries that dotted the English landscape. Chantries had several benefits in that they enabled patrons to establish 'personalised intercessory foundations' (135) and that specific individual clergymen, rather than entire clerical communities, were made responsible for praying for the soul of the benefactor and those named by him. Due to the stipulations of the Fourth Lateran Council (1215), the offering of masses rather than the recitation of prayers and hymns became the fundamental task of chantry priests.

Chantries had another advantage which contributed to the formation of strong links between the English gentry and parish churches: they could be established anywhere. No longer reliant on monastic communities for intercession, gentry families started to establish chantries in parish churches, something which fundamentally altered the appearance of these churches. Unlike monasteries, the structure of parish churches could be modified relatively easily in order to establish side chapels and altars where intercessory masses could be sung. Indeed, as Saul convincingly argues, partly on the basis of a great number of visual sources, 'it was chantry foundation which set in motion the process by which the gentry took over and colonized the space of the local parish church for own personal use' (142). From around the middle of the thirteenth century, an increasing number of parish churches became dominated by the gentry. In conjunction with the territorialisation of their power base, gentry families were keen to found chantries in the parish church near their families' seat: such foundations, although primarily religious in nature, were used to affirm and strengthen a family's status in the locale. The adornment of churches by all kinds of heraldic display further emphasised the elevated status of the patron and his or her family.

Through the examination of burial sites and funerary monuments, Saul shows the close ties between the gentry and 'their' parish churches and the extent to which these churches were turned into family or dynastic mausoleums. Such links were also visualised through, for example, the inclusion of the church in the moat encircling the manor (269). In addition to the architectural patronage of existing churches, a number of gentry families constructed churches de novo, a forceful expression of status and wealth which only a few families could afford. Whether through the patronage of existing churches or the construction of new ones, the resulting 'gentry churches' shared a number of characteristics, including a richly decorated interior, a range of heraldic display, and a location near or even inside the manorial complex. Within the churches, gentry families appropriated and compartmentalized space, for example by demarcating the side chapels where soul masses for gentry patrons were celebrated. Still, as Saul argues, 'the desire for intercession ultimately subverted any notion of a complete separation between the gentry in church and the rest of the parish' (306). Different processes were at work in gentry churches: while on the one hand the elevated social status of gentry families had to be emphasised, at the same time it was in the 
interests of gentry families to be regarded as a firm part of the parish community and be included in communal acts of intercession. Through institutionalized intercession as well as funeral monuments and other forms of architectural patronage, gentry churches became sites of 'chivalric remembrance' (197) and 'family and dynastic memory' (328).

In spite of the increasing importance of the local church for the gentry's territorial and landed identities, rival institutions that were under the gentry's control to an even larger extent had the potential to challenge the participation of the gentry in the religious life of the parish. Many a manor house was equipped with a private chapel in which gentry families and members of their household could practice their faith. Certain privileges were extended by chapel grants and, later, episcopal licenses, such as the permission to celebrate mass in these chapels. The ecclesiastical authorities were keen, though, to ensure that the owners of private chapels continued to participate in the religious life of the parish at regular intervals. Their stipulations, in combination with the fact that the gentry tended to attend parish churches for the traditional rites of passage, prevented gentry families from secluding themselves from the parish. Moreover, prevailing notions of lordship ensured the close involvement of the gentry with the parish, visible in their roles as advocates of parish communities and benefactors of parish churches. In reaction to the work of Colin Richmond in particular, Saul convincingly argues that the gentry remained integrated in the (religious) life of the parish throughout the period under study.

Saul's aims in writing this book are to 'subject the debates and discussions about the gentry's relationship with the parish and the parish church to a critical review and, second, to move the agenda forward to attempt an overall interpretation of the changing dynamics of that relationship in the medieval period'. By providing a lucid and rich synthesis of the relationships between the gentry and parish churches over a long time span and the many developments which influenced these relationships, the author has certainly achieved these goals. Still, he could have been more forceful in stating and elucidating his own argument; this would have made the book an even more interesting read than it already is. Moreover, some of his arguments could have been developed and substantiated more fully. For example, the statement that gentry churches often were more richly decorated than churches which did not enjoy the patronage of gentry families, invites a thorough comparison of gentry and non-gentry churches. These are nothing more than some minor limitations of a stimulating and rich study, however. While this book undoubtedly is of great value for specialists in medieval history, it has a lot to offer for those interested in the link between religion and nobility in the early modern period, like myself. The rich canvas painted by Saul provides an excellent point of departure for the assessment of the (changing) relationships between the gentry and parish churches during and after Protestant and Catholic Reformations. As such, this book deserves a wide readership. 
Adellijke echo's? De invloed van de adel op de ontwikkeling van buitenplaatsen langs de rivieren van het Amstelland en de Oude Rijn

Gerrit van Oosterom

Het Staatse ambassadegebouw in de zeventiende eeuw. Het logement van Hendrick van Reede van Renswoude in Madrid, 1656-1669

Maurits Ebben

Naar het Oosten. Geografische verschillen in het ledenbestand van de Ridderlijke Duitsche Orde, Balije van Utrecht, 1640-1840

Renger E. de Bruin

De Belgische orangistische adel I. De zuidelijke adel in het Verenigd Koninkrijk 79 der Nederlanden (1815-1830)

Els Witte

The Bentinck family archives. Highlights and suggestions for further research Menoucha Ruitenberg

Bildung und Erziehung. Zur Bedeutung zweier Schlüsselkategorien für Charlotte Sophie Gräfin Bentinck

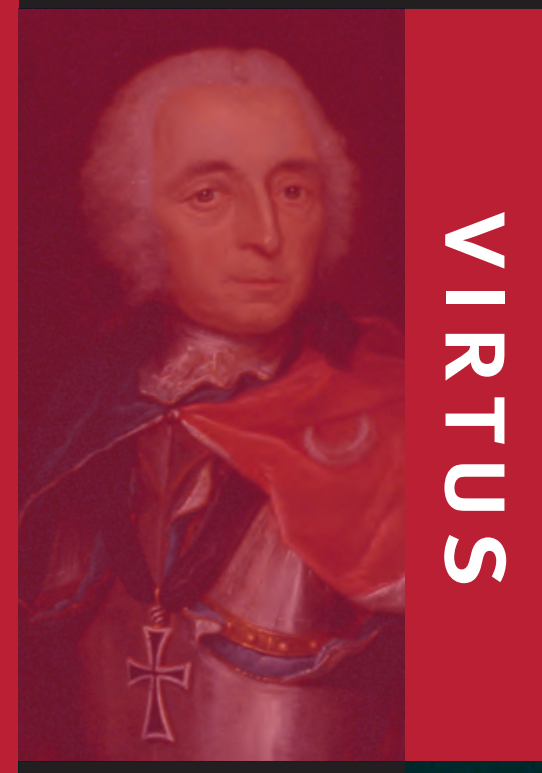

25 | 2018

Christina Randig

Charlotte Sophie, Joseph Eckhel and numismatics

Daniela Williams

Craignez honte. The Bentinck coats of arms and their use as an expression of the cross-border character of the family

\section{Olivier Mertens}

Fathers and Sons. A sketch of the noble life forms of the Bentincks in the 162 period of the Great Wars in Europe (1672-1748)

Yme Kuiper

Van wapenbord tot koningsboek. Herinnering, herstel en herbestemming in de heraldiek van het Gulden Vlies (1559-1795)

Steven Thiry 